\title{
Phytochemical Screening and Evaluation of Cytotoxicity and Thrombolytic Properties of Achyranthes Aspera Leaf Extract
}

\author{
Md. Jakir Hossain ${ }^{1}$, Laila Khaleda ${ }^{2}$, A.M. Masudul Azad Chowdhury ${ }^{3}$, Md. \\ Arifuzzaman ${ }^{4}$ and Mohammad Al-Forkan* ${ }^{5}$ \\ 1, 2, 3 \& 5 Department of Genetic Engineering and Biotechnology, University of Chittagong, Chittagong-4331, \\ Bangladesh. \\ ${ }^{4}$ Department of Biochemistry and Biotechnology, University of Science and Technology, Chittagong (USTC), \\ Foy's Lake, Chittagong-4202, Bangladesh
}

\begin{abstract}
The rural and marginal people of Bangladesh are deprived of modern treatment facilities and hence greatly depend on medicinal plants. Besides, the higher cost and toxicity of synthetic drugs drives scientists towards search for natural source of medication for a number of diseases. Cost-effectiveness, easy availability and fewer side effects are making the herbal medicine more popular both among rural and city people. Plants with Cytotoxic and clot lysis potential are good candidate as source of novel anti-tumor agents and thrombolytic drugs. This study aimed at screening out of phytochemical constituents and evaluation of cytotoxicity and thrombolytic potential of an important medicinal plant Achyranthes aspera methanolic leaf extract. In vitro phytochemical screening of A. aspera leaf extract carried out by qualitative tests revealed the presence of alkaloids, glycosides, cardiac glycosides, flavonoids, tannins, terpenoids, steroids and saponins while phlobatannins were absent. Cytotoxicity test of A. aspera leaf extract carried out by Brine shrimp Lethality (BSL) Bioassay showed the highest percentage of mortality (90\%) in $1250 \mu \mathrm{g} / \mathrm{ml}$ and LC50 value was $50.12 \mu \mathrm{g} / \mathrm{ml}$. Thrombolytic test showed $32.87 \pm 9.42 \%$ clot lytic activity for A. aspera while positive control (streptokinase) and negative control (water) showed $81.19 \pm 3.78 \%$ and $6.67 \pm 2.58 \%$ clot lysis, respectively. Synergistic effect of streptokinase and A. aspera extract also produced better result $(56.30 \pm 6.95 \%)$ than A. aspera alone.
\end{abstract}

Keywords: Achyranthes aspera, cytotoxic, thrombolytic, phytochemical screening, LC50

\section{Introduction}

There exists a plethora of knowledge, information and benefits of herbal drugs in ancient literature of Ayurvedic and Unani medicine. The plant kingdom represents a rich store house of organic compounds, many of which have been used for medicinal and other purpose. Natural products, either pure compounds, or as standardized plant extracts, provide greater opportunities for new drug leads because of the great availability of chemical diversity [1]. Plants with medicinal values are used in throughout the world and from ancient times and are a source of many potent and powerful drugs [2], [3] and [4]. Achyranthes aspera is a perennial herb belonging to the family of Amaranthaceae. It grows throughout the tropical and warmer regions of the world [5]. It was reported as an invasive alien species in northern Bangladesh [6]. Achyranthes aspera was reported to contain many phytochemicals like alkaloids, flavonoids, tannins, terpenoids, saponins, glycosides, steroids etc. In India and China, this plant is extensively used as anti-microbial [7], [8], cancer chemo-preventive [9], hepatoprotective [10], analgesic [11], anti-inflammatory and anti-arthritic [12], hypolipidemic [13], nephroprotective [14], diuretic [15] and immunomodulatory [16] etc.

Cancer, manifested by abnormal cellular proliferation is the world's leading cause of death that claims millions of lives annually. The estimated worldwide incidence of different carcinomas is about 10 million; half of these are in developed countries [17]. In the USA, 30-75\% of the cancer patients use complementary and alternative medicines, which are mainly of plant origin [18]. Cancer chemotherapeutic drugs aim at killing abnormal cells in cancerous tissue or organ. However, these chemotherapeutics are mostly synthetic and suffer from some drawbacks. Research interest on screening of medicinal plants for novel chemotherapeutic agents is increasing in recent years [19]. Hence, it is necessary to look for cytotoxic compounds in plants, in order to develop a therapeutic that targets only rapidly dividing cancer cells. But exposure of cancer patients with plant products was proved detrimental in some instances. Therefore it is necessary to assay the safety profile of plants used in treatment [20]. Plant derived bioactive compounds are always toxic to living body at some higher doses. Cytotoxicity screening tests provide important information to help selecting plant extracts with potential antineoplastic properties for future work [21]. Many medicinal plants in Bangladesh hold the promise to be effective as cytotoxic drug and hence, a great detail of investigation needed in this regard.

Unobstructed and continuous blood flow is crucial function of circulatory system and a failure in 
continuous blood flow through blood vessels are life threatening in many cases. Thrombi or clot can lodge in a blood vessel and block the flow of blood in that organ or tissue depriving tissues of normal blood flow and oxygen. This can result in damage, destruction (infarction), or even death of the tissues (necrosis) in that area. A blood clot (thrombus) is formed from fibrinogen by thrombin and is lysed by plasmin, which is activated from plasminogen by tissue plasminogen activator (tPA). Fribrinolytic drugs have been used to dissolve thrombi in acutely occluded coronary arteries thereby to restore blood supply to ischaemic myocardium, to limit necrosis and to improve prognosis [22]. Atherothrombotic diseases such as myocardial or cerebral venous sinus thrombosis (CVST) are common disorders that often lead to mortality due to thrombus (clot) formed in blood vessel [23], [24]. Thrombolytic therapy uses drugs called thrombolytic agents, such as alteplase ,anistreplase, streptokinase, urokinase, and tissue plasminogen activator (TPA) to dissolve clots. Streptokinase is an antigenic thrombolytic agent frequently used for clot lysis in the treatment of acute myocardial infarction and other athrombotic disease. But the main disadvantage of streptokinase therapy is the dissolution of all thrombi, both the protective ones preventing hemorrhage and the life-threatening ones. Some other side effects like nausea, vomiting and adverse bleeding are also observed in some cases [25], [26], [27]. Medicinal herbs are considered to provide thrombolytic drugs without such drawbacks [28]. Therefore, developments of low cost and more effective thrombolytic drugs with minimum adverse reactions from medicinal plants are attempted by many researchers in current years. Shortcomings of the available thrombolytic drugs lead researchers to develop improved recombinant variants of these drugs from natural sources like medicinal plants [29]; [30].

In this experiment, first $A$. aspera leaves were extracted in methanol, a preliminary phytochemical screening was conducted and subsequently this plant extract was evaluated for cytotoxic and thrombolytic potential.

\subsection{Collection of plant and Preparation of plant extract}

\section{Materials And Methods}

The fresh and healthy leaves of Achyranthes aspera were collected from Chittagong University Campus area. The plant was taxonomically classified and authenticated by standard taxonomical method.

The fresh leaves of plant of Achyranthes aspera was washed with clean water immediately after collection. The collected leaves were chopped into small pieces, sun dried for about 5 days and grinded into coarse powder with a mechanical grinder and stored in an airtight container. 166 gm powder was macerated in $700 \mathrm{ml} 95 \%$ pure methanol (Sigma Chemicals Co., USA) for 5 days at room temperature $25 \pm 2^{0} \mathrm{C}$ with occasional stirring. After 5 days, methanol extract was filtered with Whatman No.1 filter paper. The extract was concentrated under reduced pressure below $50^{\circ} \mathrm{C}$ through rotary vacuum evaporator [31]. The concentrated extract was collected in a Petri dish and allowed to air dry for complete evaporation of methanol. The whole process was repeated three times and finally, 14.77gm blackish-green colored, concentrated plant extract was obtained (yield $8.9 \% \mathrm{w} / \mathrm{w}$ ) which was kept in refrigerator at $4^{0} \mathrm{C}$. The extract thus obtained is ready for subsequent therapeutic assessments.

Yield calculation $=\frac{\text { Weight of particular extract }}{\text { Total amount of coarse powder }}$ X100

\subsection{Methods for phytochemical screening tests Test of alkaloids Mayer's test}

$0.5 \mathrm{~g}$ extract was stirred with $5 \mathrm{ml} 1 \% \mathrm{HCl}$ on a steam bath and then mixture was flitered. $1 \mathrm{ml}$ of filtrate was treated with a few drop of Mayer's reagent. White or creamy white precipitate indicates the presence of alkaloid [32].

\section{Wagner's test}

$0.5 \mathrm{~g}$ extract was stirred with $5 \mathrm{ml} 1 \% \mathrm{HCl}$ on a steam bath and flitered. $1 \mathrm{ml}$ of filtrate was treated with a few drop of Wagner's reagent. Brown or deep brown precipitate indicates the presence of alkaloids [32].

\section{Hager's test}

$0.5 \mathrm{~g}$ extract was stirred with $5 \mathrm{ml} 1 \% \mathrm{HCl}$ on a steam bath and flitered. $1 \mathrm{ml}$ of filtrate was treated with a few drop of Hager's reagent. Yellow crystalline precipitate indicates the presence of alkaloids [32].

\section{Test of glycosides \\ General test}

Small amount of an alcoholic extract of the fresh or dried material was dissolved in $1 \mathrm{ml}$ of water. A few drops of aqueous $\mathrm{NaOH}$ solution were added. Yellow color indicates the presence of glycoside. 


\section{Test of cardiac glycosides}

\section{a) Legal's test}

$0.1 \mathrm{gm}$ of an alcoholic extract of plant material was dissolved in $2 \mathrm{ml}$ of Sodium nitroprusside solution $(0.5 \%)$. The mixture was made alkaline with $\mathrm{NaOH}(0.2 \mathrm{~N})$ solution. Pink to red color indicates the presence of cardiac glycosides due to lactone ring.

\section{b) Baljet test}

A drop of Baljet's reagent (picric acid $+\mathrm{NaOH}$ ) was added to a portion of an alcoholic extract of plant material. A yellow orange color was produced due to the presence of five member lacton ring at C-17 of the aglycone in cardiac glycoside.

Test of flavonoids [33].

\section{General test}

A small amount of an alcoholic extract of the plant material was taken. Few drops of conc. $\mathrm{HCl}$ was added. Immediate development of red color indicates the presence of flavonoids.

\section{Specific test}

About $0.5 \mathrm{ml}$ of an alcoholic extract of the sample was taken in a test tube. A small piece of magnesium or zinc ribbon was added. Then 5-10 drops of concentrated $\mathrm{HCl}$ was added. The solution was was boileded for few minutes. Development of orange to red, red to crimson, crimson to magenta indicate flavones, flavanols, and flavanones respectively.

\section{Test of terpenoids}

\section{Salkowski test}

$0.1 \mathrm{gm}$ of plant extract was taken in a test tube. $1 \mathrm{ml}$ of chloroform and then $1 \mathrm{ml}$ of conc. sulfuric acid was added from the side of the test tube. A red color is produced in the chloroform layer if terpenoid is present. [33].

\section{Test of tannins}

$\mathrm{FeCl}_{3}$ test

About $0.5 \mathrm{gm}$ of the dried powdered samples was was boileded in $20 \mathrm{ml}$ of water in a test tube and then filtered. A few drops of $0.1 \%$ ferric chloride was added and observed for brownish green or a blue-black coloration [34].

\section{Test of phlobatannins}

$0.1 \mathrm{gm}$ of plant extract was taken in a test tube. Then it was was boileded with $1 \%$ aqueous $\mathrm{HCl}$. Deposition of a red precipitate was taken as an evidence for the presence of phlobatannins [34].

\section{Test of steroid}

\section{Libermann-Burchard's test}

A small amount $(0.1 \mathrm{gm})$ of plant extract was taken in a test tube and dissolved in $1 \mathrm{ml}$ of chloroform. $2 \mathrm{ml}$ of acetic anhydride and then $1 \mathrm{ml}$ of concentrated sulfuric acid was added. A greenish color was formed indicating the presence of steroid [34].

\section{Test of saponin}

\section{Frothing test}

$0.5 \mathrm{gm}$ of an alcoholic extract was taken in a test tube and shaken with $5 \mathrm{ml}$ of distilled water. Formation of stable foams indicated the presence of saponin [32].

\subsection{Assay of Cytotoxicity of $A$. aspera leaf methanol extract}

Cytotoxic activity of Achyranthes aspera methanolic leaf extract was determined by Brine-Shrimp Lethality 
(BSL) Bioassay as described by [35], [36], [37].

\section{Procedure of hatching of Brine shrimp egg}

The cysts (eggs) of the Brine shrimp were decapsulated in $200 \mathrm{ppm}$ chlorine water for 15-20 minutes. Then the cysts were washed thoroughly with fresh water till all the chlorine gas escapes and cysts were then taken in a conical hatching container and filtered (clean) seawater was added. Soaking density was 1-2 gm of cysts per litre of seawater. Moderate aeration was supplied from the bottom of the container at the rate of 10 to 20 litre of air per minute. The container was kept under illumination using a white lamp for $48 \mathrm{~h}$ for the eggs to hatch into shrimp larvae (nauplii). Then the nauplii were harvested in a beaker.

\section{Preparation of sample}

In a small beaker, $50 \mathrm{mg}$ of the sample was accurately weighed and dissolved in $5 \mathrm{ml}$ DMSO (Dimetylsulfoxide) to give a concentration of $10 \mathrm{mg} / \mathrm{ml}$. From this stock, $1 \mathrm{ml}$ of the sample (A. aspera leaf extract) was taken and $19 \mathrm{ml}$ water was added to give a final working concentration of $500 \mu \mathrm{g} / \mathrm{ml}$.

\section{Procedure of Brine shrimp lethality bioassay}

a. 15 test tubes were taken where each contain $5 \mathrm{ml}$ sea water and 10 naupli. In each test tube 10 nauplii were transferred with Pasteur pipette.

b. The test tubes were marked from 1 to 14 for sample and 15 no. test tube was marked as control (no extract).

c. In test tube $1,2.5 \mathrm{ml}$ of the sample was added to give total amount of $1250 \mu \mathrm{g}$ of the sample (concentrations $166.67 \mu \mathrm{g} / \mathrm{ml}$ ).Similarly $2 \mathrm{ml}, 1.75 \mathrm{ml}, 1.50 \mathrm{ml}, 1.25 \mathrm{ml}, 1 \mathrm{ml}, 0.75 \mathrm{ml}, 0.5 \mathrm{ml}, 0.25 \mathrm{ml}, 0.2 \mathrm{ml}, 0.175 \mathrm{ml}$, $0.075 \mathrm{ml}, 0.050 \mathrm{ml}, 0.025 \mathrm{ml}$ of the sample were added to give a amount of $1000,875,750,625,500,375$, $250,125,100,87.5,37.5,25$, and $12.5 \mu \mathrm{g} / \mathrm{ml}$ of the sample in the test tube no. $2,3,4,5,6,7,8,9,10,11$, 12,13 , and 14 , respectively.

d. For control, $50 \mu \mathrm{l}$ DMSO was added in $5 \mathrm{ml}$ sea water containing 10 naupli. No extract was added to prepare control solution. DMSO should not exceed $50 \mu$ l.

e. Each concentration was tested in triplicate.

f. The test tubes were maintained under illumination. After 24 hours have elapsed, Survivors were counted with the aid of a $3 \mathrm{X}$ magnifying glass.

g. $\log C$ for each concentration was calculated and probit value for each $\%$ of mortality was calculated from probit chart.

h. The LC50 values were calculated from the linear regression equation obtained by plotting each Log concentrations against respective probit values in the graph. Computer software "BioStat-2009" was also used for calculating LC50 value.

\subsection{Determination of Thrombolytic activity Streptokinase (SK) solution preparation}

To the commercially available lyophilized SK vial (PolaminWerk GmbH, Herdecke, Germany) of 15,00,000 I.U., $5 \mathrm{ml}$ sterile distilled water was added and mixed properly. This suspension was used as a stock from which $100 \mu \mathrm{l}(30,000$ I.U.) was used for in vitro thrombolysis.

\section{Specimen}

With all aseptic condition $5 \mathrm{ml}$ of whole blood was drawn from healthy human volunteers $(\mathrm{n}=10)$ without a history of oral contraceptive or anticoagulant therapy(using a protocol approved by the Institutional Ethics Committee of Central India Institute of Medical Sciences, Nagpur). $500 \mu 1(0.5 \mathrm{ml})$ of blood was transferred to each of the ten previously weighed ependorff tubes to form clots.

\section{Herbal preparation}

$100 \mathrm{mg}$ methanolic extract of leaves of Achyranthes aspera was suspended in $10 \mathrm{ml}$ distilled water and the suspension was shaken vigorously on a vortex mixer. The suspension was kept overnight and decanted to remove the soluble supernatant, which was filtered through a 0.22 -micron syringe filter. $100 \mu \mathrm{l}$ of this aqueous preparation of herb was added to the eppendorff tube containing the clots to check thrombolytic activity.

\section{Procedure of clot lysis assessment}

$5 \mathrm{ml}$ venous blood drawn from healthy volunteers was distributed in ten different pre weighed sterile eppendorff tubes $(0.5 \mathrm{ml} / \mathrm{tube})$ and incubated at $37^{\circ} \mathrm{C}$ for 45 minutes. After clot formation, serum was completely removed without disturbing the clot and each tube having clot was again weighed to determine the clot weight (Clot weight $=$ weight of clot containing tube - weight of tube alone) [26].To each eppendorf tube 
containing pre-weighed clot, $100 \mu \mathrm{l}$ of aqueous extract of Achyranthes aspera was added. As a positive control, $100 \mu \mathrm{l}$ of Streptokinase solution and as a negative non thrombolytic control, $100 \mu \mathrm{l}$ of distilled water were separately added to the control tubes. All the tubes were then incubated at $37^{\circ} \mathrm{C}$ for 90 minutes and observed for clot lysis. After incubation, fluid released was removed and tubes were again weighed to observe the difference in weight after clot disruption. Difference obtained in weight taken before and after clot lysis was expressed as percentage of clot lysis. The experiment was repeated several times with the blood samples of volunteers.

$$
\text { Percentage of clot ly sis }=\frac{\text { Weight of clot lysed }}{\text { Weight of clot before ly sis }} \times 100
$$

\section{Statistical analysis}

The significance between \% clot lysis by Streptokinase, herbal extract, water by means of weight difference was tested by the paired t-test analysis. Data were expressed as mean \pm standard deviation.

\section{a. Phytochemical screening tests}

\section{Results And Discussions}

The crude methanolic leaf extract of A. aspera was subjected to many chemical tests to confirm the presence or absence of different types of phytochemical constituents that confer therapeutic values to the plant. The phytochemical characters of this medicinal plant (Achyranthes aspera) investigated are summarized in Table 1:

Table 1: Results of Phytochemical screening

\begin{tabular}{|l|l|l|c|}
\hline Phytochemicals & Name of the test & \multicolumn{1}{c|}{ Observation } & Result \\
\hline \multirow{4}{*}{ Alkaloids } & Mayer's test & Creamy white precipitate & + \\
\cline { 2 - 4 } & Wagner's test & $\begin{array}{l}\text { Brown or deep brown } \\
\text { precipitate }\end{array}$ & + \\
\cline { 2 - 4 } & Hager's test & Yellow crystalline precipitate. & + \\
\hline Glycosides & General test & Yellow color. & + \\
\hline $\begin{array}{l}\text { Cardiac } \\
\text { glycosides }\end{array}$ & Legal's test & Pink to red color. & + \\
\cline { 2 - 4 } Terpenoids & Baljet's test & Yellow orange color. & + \\
\hline \multirow{2}{*}{ Flavonoids } & Salkowski test & A reddish brown coloration & + \\
\cline { 2 - 4 } Steroids & General test & Rose pink in the aqueous layer & + \\
\hline Tannins & $\begin{array}{l}\text { Libermann-Burchard's } \\
\text { test }\end{array}$ & Orange to red color & + \\
\hline Phlobatannins & FeCl ${ }_{3}$ test & Greenish color & + \\
\hline Saponins & Frothing test & Brownish green color & + \\
\hline
\end{tabular}

N.B: "+" stands for presence and "-" for absence.

The qualitative phytochemical screening confirmed the presence of alkaloids, glycosides, cardiacglycosides, terpenoids, flavonoids, steroids, tannins, and saponins and absence of phlobatannins in A. aspera methanolic leaf extract. Umamaheswari et al. also reported the presence of alkaloids, flavonoids, saponins, tannins, terpenoids and phenolics in this plant [38]. The presence of this phytochemicals makes this plant a potential candidate for using in different therapeutic conditions. Alkaloids are believed to have anti-cancer, antimalarial, nervous stimulant and many more properties. Achyranthine, a water soluble alkaloid from A. aspera were reported to have better activity in cardiovascular problems [39]. Flavonoids are synthesized by plants in response to microbial infection and reported to have better anti-microbial properties [40]. Flavonoids are potent super antioxidants and free radical scavengers [41], have strong anti-cancer activity and re-duce the risk of heart diseases [42]. In terms of anti-cancer activity, they inhibit the initiation, promotion and progression of tumors [43]. The presence of tannins are supposed to confer the plant many physiological activities such as stimulation of phagocytic cells and host mediated tumor activity [43]. The presence of saponins is attributed to lowering cholesterol and to exhibit structure dependent biological activity which is also used as an expectorant and an emulsifying agent [40]. Presence of steroids and steroidal compounds are of importance and interest in pharmacy due to their role as sex hormones crucial in reproduction [44].

\section{b. Cytotoxicity test}

Cytotoxic activity of Achyranthes aspera leaf methanol extract was determined by Brine Shrimp Lethality (BSL) Bioassay [36]. Percentage of lethality of brine shrimp at fourteen different concentrations (1250 to $12.5 \mu \mathrm{g}$ ) of Achyranthes aspera methanol extract and in control (no extract) is presented in Table 4.6. Plant extract showed lethality in a dose dependent manner. More specifically, 90\%, 90\%, 80\%, 80\%, 70\%, 50\%, 50\%, 
$40 \%, 30 \%, 20 \%, 10 \%$ and $10 \%$ mortality of brine shrimp was observed at 166.67, 142.86, 129.63, 115.38, 100, $83.33,65.22,45.45,23.81,19.23,16.91$ and $7.39 \mu \mathrm{g} / \mathrm{ml}$ concentrations, respectively. In low concentrations of plant extract $(4.95$ and $2.49 \mu \mathrm{g} / \mathrm{ml})$ and in the control there was no lethality $(0 \%)$. It was evident from the result that with the increase in concentrations of plant extract, the percentage of mortality of brine shrimp also increases and the minimum and maximum value was $10 \%$ and $90 \%$ observed at 7.39 and $1250 \mu \mathrm{g} / \mathrm{ml}$, respectively.

From the lethality percentage of brine shrimp, the probit values were calculated for each concentration by using Probit table and computer program "BioStat-2006". Probit values were then plotted against corresponding Log concentrations of plant extract. There is no probit value for $0 \%$ or $100 \%$ mortality. Hence, only the concentrations that have corresponding probit values were the ones we plotted in the graph and used in calculating LC50. From this graph, LC50 (lethal concentration 50) value was found by regression analysis using computer program "BioStat-2006" or simple calculation using regression equation (Table 2 and Fig.1). LC50 value of Achyranthes aspera methanol extract was observed to be $50.12 \mu \mathrm{g} / \mathrm{ml}$. There was a good linearity obtained in regression line for mortality rates at different concentrations of extract indicated by $\mathrm{R}^{2}$ value of 0.916 (Fig. 1). This result was found superior than previous report in the same plant [45]. Crude extracts resulting in LC50 values of less than $250 \mu \mathrm{g} / \mathrm{ml}$ is usually considered significantly active and potential for further investigation [46]. Therefore, A. aspera contains moderate cytotoxic activity. The bioassay has a good correlation with cytotoxic activity in some human solid tumors and with pesticidal activity [47]. This in-vivo lethality test has been successively employed for providing a frontline screen that can be backed up by more specific and more sophisticated bioassays. Phytochemicals like steroid, tannins and flavonoids present in the extract may be responsible for the cytotoxic activity observed. Hence, the plants may therefore be a potential source for the discovery of new cytotoxic compounds.

Table 2: Determination of brine shrimp cytotoxicity for different concentrations of Achyranthes aspera leaf methanolic extract

\begin{tabular}{|c|c|c|c|c|c|c|c|c|c|}
\hline $\begin{array}{c}\text { No. of test } \\
\text { tube }\end{array}$ & $\begin{array}{c}\text { Total } \\
\text { amount } \\
\text { of } \\
\text { sample } \\
(\mu \mathrm{g})\end{array}$ & $\begin{array}{l}\text { Sample } \\
\text { Vol. } \\
(\mathrm{ml})\end{array}$ & 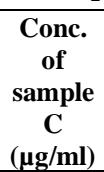 & $\log C$ & $\begin{array}{c}\text { No. of } \\
\text { Nauplii } \\
\text { Taken }\end{array}$ & $\begin{array}{l}\text { No. of dead } \\
\text { nauplii } \\
\text { (After } \\
\text { treatment) }\end{array}$ & $\begin{array}{c}\% \text { of } \\
\text { mortality }\end{array}$ & $\begin{array}{l}\text { Probit } \\
\text { value }\end{array}$ & $\begin{array}{l}\text { LC 50 } \\
\text { value }\end{array}$ \\
\hline 1 & $\begin{array}{c}1250.0 \\
0\end{array}$ & 2.50 & $\begin{array}{c}166.6 \\
7\end{array}$ & 2.22 & 10 & 9 & 90 & 6.28 & \multirow{15}{*}{$\begin{array}{l}50.12 \\
\mu \mathrm{g} / \mathrm{ml}\end{array}$} \\
\hline 2 & $\begin{array}{c}1000.0 \\
0\end{array}$ & 2.00 & $\begin{array}{c}142.8 \\
6\end{array}$ & 2.15 & 10 & 9 & 90 & 6.28 & \\
\hline 3 & 875.00 & 1.75 & $\begin{array}{c}129.6 \\
3\end{array}$ & 2.11 & 10 & 8 & 80 & 5.84 & \\
\hline 4 & 750.00 & 1.50 & $\begin{array}{c}115.3 \\
8\end{array}$ & 2.06 & 10 & 8 & 80 & 5.84 & \\
\hline 5 & 625.00 & 1.25 & 100 & 2 & 10 & 7 & 70 & 5.52 & \\
\hline 6 & 500.00 & 1.00 & 83.33 & 1.92 & 10 & 5 & 50 & 5.00 & \\
\hline 7 & 375.00 & 0.75 & 65.22 & 1.81 & 10 & 5 & 50 & 5.00 & \\
\hline 8 & 250.00 & 0.50 & 45.45 & 1.66 & 10 & 4 & 40 & 4.75 & \\
\hline 9 & 125.00 & 0.25 & 23.81 & 1.38 & 10 & 3 & 30 & 4.48 & \\
\hline 10 & 100.00 & 0.20 & 19.23 & 1.28 & 10 & 2 & 20 & 4.16 & \\
\hline 11 & 87.50 & 0.175 & 16.91 & 1.23 & 10 & 1 & 10 & 3.72 & \\
\hline 12 & 37.50 & 0.075 & 7.39 & 0.87 & 10 & 1 & 10 & 3.72 & \\
\hline 13 & 25.00 & 0.050 & 4.95 & 0.69 & 10 & 0 & 0 & - & \\
\hline 14 & 12.50 & 0.025 & 2.49 & 0.40 & 10 & 0 & 0 & - & \\
\hline $\begin{array}{c}15 \\
\text { (Control } \\
\text { ) }\end{array}$ & 0 & $\begin{array}{c}\text { contro } \\
1\end{array}$ & 0 & 0 & 10 & 0 & 0 & - & \\
\hline
\end{tabular}

Note: There is no probit value for $0 \%$ and $100 \%$ 


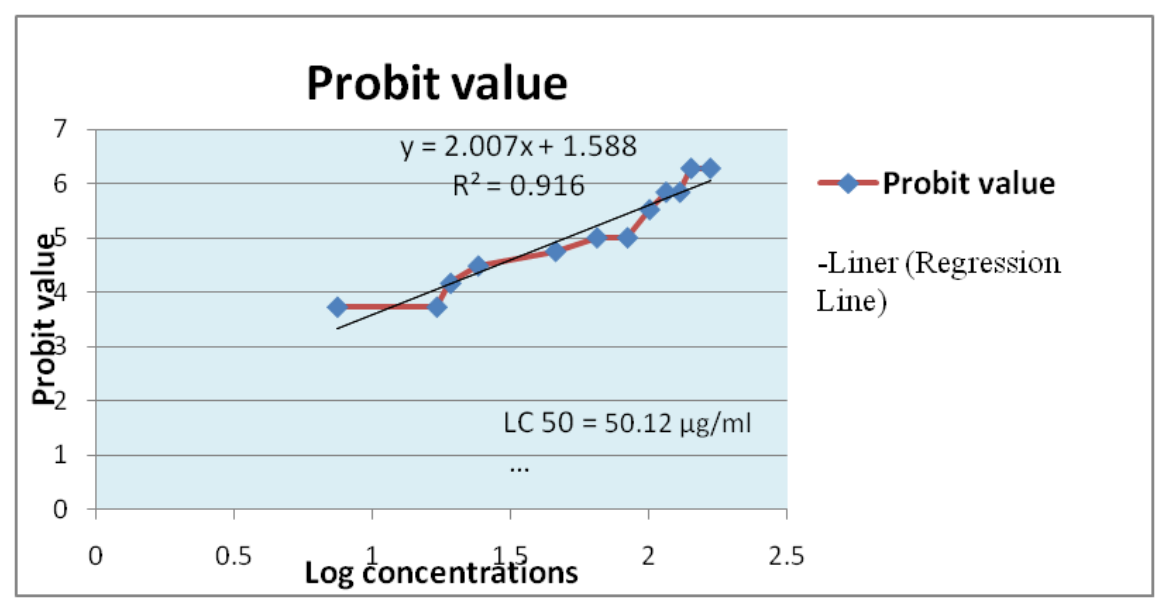

Fig. 1: Regression line for determining the LC50 value of Achyranthes aspera methanol extract.

\section{c. In vitroThrombolytic activity of $A$. aspera leaf extract}

Atherothrombotic diseases are a great concern in present world and most thrombolytic drugs lack specificity and have adverse reactions. Hence, herbal drugs may be a better alternative for treating thrombotic diseases [28]. Streptokinase was used as positive control because it is a common and most potent thrombolytic drug and distilled water was used as negative control to compare the thrombolytic activity of the plant extract. There were 15 replications for A. aspera leaf extract and 5 replications for both streptokinase and water. Maximum clot lysis activity was observed in clot treated with streptokinase (SK) which was $81.19 \pm 3.78 \%$. A. aspera showed $32.87 \pm 9.42 \%$ clot lysis while water (as a negative control) showed poor clot lysis activity which was only $6.67 \pm 2.58 \%$. The mean difference in clot lysis percentage between positive and negative control was very significant $(* * *$ p value $<0.0008)$. To explore, whether the plant extract of A. aspera has any synergistic effect with Streptokinase or not, clot lysis activity of plant extract along with Streptokinase was carried out. $100 \mu$ l of $A$. aspera extract along with $100 \mu$ of streptokinase was added in each eppendorff tube. 5 replications were done for determining synergistic effect. The result showed $56.30 \pm 6.95 \%$ clot lysis activity for synergistic effect of $A$. aspera extract and streptokinase which was significantly higher than clot lysis percentage of A. aspera extract alone (Table 3 and Fig. 2). Statistical representation (paired t-test) of the effective clot lysis percentage by herbal preparations (extract of A. nigra), positive control (Streptokinase) and negative control (sterile distilled water) was done by paired t-test analysis; clotlysis $\%$ is represented as mean \pm S.D. and is tabulated in Table 1. A P value $<0.05$ was considered as significant. The mean percentage (Mean \pm S.D) of clot lysis activity for A. aspera was found to be $32.87 \pm 9.42 \%$ whereas streptokinase produced $81.19 \pm$ $3.78 \%$ and water produced only $6.67 \pm 2.58 \%$ (Table 3 and Fig.2). The mean difference between positive and negative control varied significantly as a $\mathrm{P}$ value was found to be $<0.0008$. The synergistic effect of streptokinase and plant extract was also investigated. The percentage of clot lysis increased significantly to $56.30 \pm 6.95 \%$ in synergistic action which was much better than A. aspera alone. This indicated that this plant contain some phytochemical constituents that is responsible for this clot lysis activity. Although the percentage of clot lysis was moderate (32.87\%) compared to streptokinase $(81.19 \%)$, still this is a promising result. The uniqueness lies in that no previous reports are available regarding thrombolytic activity of this plant. This is the first attempt to investigate thrombolytic activity of A. aspera. Since, the crude extract of Achyranthes aspera exhibited $32.87 \%$ clot lysis, the purified active compound responsible for this activity is expected to show more significant thrombolytic activity. This compound being isolated and purified can be exploited for formulating new recombinant and ideal thrombolytic drug. Ideal thrombolytic drugs aim at rapid reperfusion, have a high sustained potency rate, be specific for recent thrombi, be easily and rapidly administered, create a low risk for intra-cerebral and systemic bleeding, have no antigenicity, adverse hemodynamic effects, or clinically significant drug interaction, and be cost effective. The mechanism of action and active compounds of clot lysis activity of A. aspera is still unknown. This is only a preliminary study and to make final comment the extract need thorough investigation to confirm its clot lysis activity in large scale study and in in vivo conditions. 
Table 3: Summary of the results showing effect of herbal extract, Streptokinase and water on in vitro clot lysis and also the synergistic effect of herbal extract and streptokinase:

\begin{tabular}{|c|c|c|}
\hline Treatments & $\begin{array}{c}\text { \% of clot } \\
\text { lysis } \\
\text { (Mean } \pm \\
\text { S.D.) }\end{array}$ & $\begin{array}{c}\text { P value when } \\
\text { compared to } \\
\text { negative control }\end{array}$ \\
\hline Achyranthes aspera leaf extract & $32.87 \pm 9.42$ & $<0.0001$ \\
\hline Streptokinase (positive control) & $81.19 \pm 3.78$ & $<0.0009$ \\
\hline Distilled Water (Negative control & 6.672 .58 & \\
\hline $\begin{array}{l}\text { A. aspera extract+ streptokinase } \\
\text { (Synergistic) }\end{array}$ & $56.30 \pm 6.95$ & $<0.0001$ \\
\hline
\end{tabular}

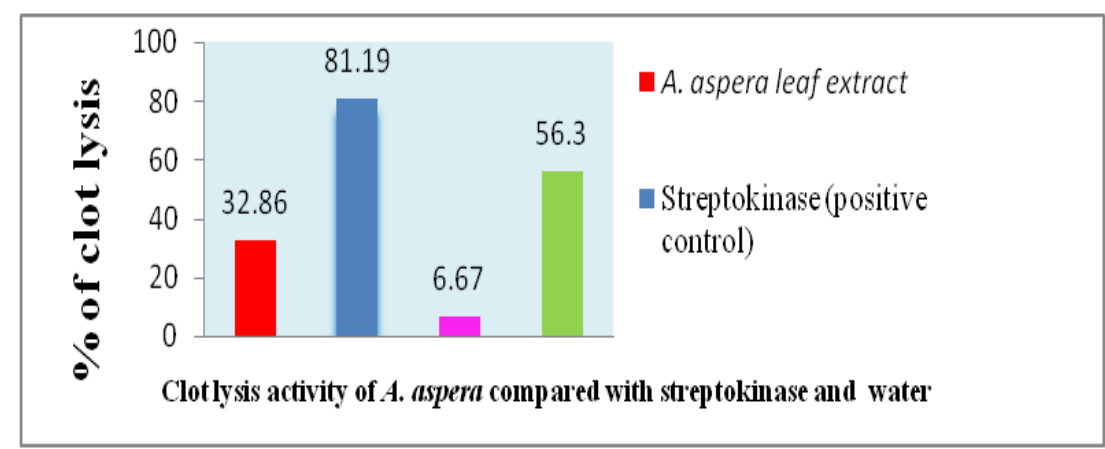

Fig. 2: Comparative study of Clot lysis by Streptokinase, Distilled water and acquous extract of Achyranthes aspera

\section{Conclusion}

Assessment of cytotoxicity and thrombolytic properties of Achyranthes aspera leaf extract reveals the possibility of using this plant as antitumor agent and it can be used in combination with other thrombolytic drugs in treating circulatory system disorders involving blood clot. This study yielded promising results with the crude extract. However, the identification, isolation and purification of active phytochemical constituents responsible for these therapeutic properties may lead to new drug development from this plant. Further in vitro and in vivo studies are recommended to harvest the benefits of natural medication from this plant.

\section{Acknowledgements}

The authors acknowledge the Ministry of Science and Technology, Government of the People's Republic of Bangladesh for financial support to conduct this research project.

\section{References}

[1]. Cos, P.; Vlietinck, A. J.; Vanden, B. D. and Maes, L.; Anti-infective potential of natural products: How to develop a stronger in vitro 'proof-of concept'. Journal of Ethnopharmacology 106, 2006, 290-302.

[2]. Emori, C.T. and Gaynes, R. Clinical Microbial Review, 6, 1993, 428-442.

[3]. Srivastava, J., Lambert, J. and Vietmeyer, N. J. W.k Technical Paper.No. 1996, 320.

[4]. Uniyal, K.S., Singh, N.K., Jamwal, P. and Lal, B. 2006. J. Ethnobiol., 2, 1-14.

[5]. de Lange, P.J., Scofield, R.P., Greene, T. Achyranthes aspera (Amaranthaceae), a new indigenous addition to the flora of the Kermadec Islands group. New Zealand J. Bot., 42, 2004, 167-173.

[6]. Akter, A. and Zuberi, M.I. Invasive alien species in Northern Bangladesh: Identification, inventory and impacts, International Journal of Biodiversity and Conservation, 1(5), 2009, 129-134.

[7]. Khan, M.S., Neela, F.A., Aktar, A., Rahman, M.M. and Alam, M.F. Antibacterial activity of Achyranthes aspera L.: An In- vitro study, J. Environ. Sci. Nat. Resour., 2, 2009, 45-48.

[8]. Saravanan, P., Ramasamy, V. and Shivakumar, T. Antimicrobial activity of leaf extracts of Achyranthes aspera Linn., Asian Journal of Chemistry, 20(1), 2008, 823-825.

[9]. Chakraborty, A., Brantner, A., Mukuinaka, T., Nobukuni, Y., Kuchido, M. and Konoshima, T. Cancer chemo preventive activity of Achyranthes aspera leaves on Epstein-Barr virus activation and two stage mouse skin carcinogenesis. Cancer Letters, 177(1), 2002, 1-5.

[10]. Bafna, R.A. and Mishra, H.S. Ars Pharmaceutica, 45(4), 2004, 343-351.

[11]. Sutar, N.G., Sutar, U.N., Sharma, Y.P., Shaikh, I.K. and Kshirsagar, S.S. Phytochemical investigation and pharmacological screening of leaves of Achyranthes aspera Linn. as analgesic and antipyretic. Biosciences Biotechnology Research Asia, 5(2), 2008, 841-844. 
[12]. Vijaya, K.S., Sankar, P. and Varatharajan, R. Anti-inflammatory activity of roots of Achyranthes aspera, Pharmaceutical Biology, 47(10), 2009, 973-975.

[13]. Khanna, A.K., Chander, R., Singh, C., Srivastava, A.K. and Kapoor, N.K. Hypolipidemic activity of Achyranthes aspera Linn. in normal and triton induced hyperlipemic rats, Indian J. Exp. Biol., 30(2), 1992, 128-130.

[14]. Jayakumar. T., Sridhar, M.P., Bharathprasad, T.R., Ilayaraja, M., Govindasamy, S. and Balasubramanian, M.P. Experimental studies of Achyranthes aspera (L) preventing Nephrotoxicity induced by lead in Albino rats, Journal of Health Science,55(5), 2009, 701-708.

[15]. Gupta, S.S., Bhagwat, W.A. and Ram, K.A. Indian Journal of Medical Research (1913-1988), 60(3), $1972,462-471$.

[16]. Chakrabarti, R. and Vasudeva R.Y. Achyranthes aspera stimulates the immunity and enhances the antigen clearance in Catla catla, Int. Immunopharmacol., 6, 2006, 782-790.

[17]. Cozzi, P., Mongelli, N. and Suarto, A. Recent anticancer cytotoxic agents. Curr Med Chem Anticancer Agents, 4: 2004, 93-121.

[18]. Richardson, M.A. Biopharmacologic and herbal therapies for cancer: research update from NCCAM. J. Nut. 131, 2001, 3037S3040 S.

[19]. Balunas, M. J. and Kinghorn, A. D Drug discovery from medicinal plants. Life Sci.; 78, 2005,431 - 441.

[20]. Gaillard, Y. and Pepin, G. Poisoning by plant material: review of human cases and analytical determination of main toxins by high-performance liquid chromatography-(tandem) mass spectrometry. J. Chromatography; 733: 1999, 181-229.

[21]. Cardellina, J.H., Fuller, R.W., Gamble, W.R., Westergaard, C., Boswell, J., Munro, M.H.G., Currens, M. and Boyd, M. Evolving strategies for the selection dereplication and prioritization of antitumor and HIV-inhibitory natural products extracts. Bioassaay Methods in Natural Product Research and Development. Kluwer Academic Publishers, Dordrecht, 1999, pp. 25-36.

[22]. Lawrence, D.R. and Bennett, P.N. Clinical Pharmacology: Seventh Edition 1992: Page 483.

[23]. Lee, H.S. How safe is the readministration of streptokinase :Drug Saf.; 13: 1995, 76-80.

[24]. Watson, R.D., Chin, B.S. and Lip, G.Y. Antithrombotic therapy in acute coronary syndromes .BMJ; 325: 2002, 1348-1351.

[25]. Nikhil, S. and Amit, B. A History of Streptokinase Use in Acute Myocardial Infarction,Tex Heart Inst J; 34(3), $2007,318-327$.

[26]. Sweta, P., Rajpal, S.K., Jayant, Y.D., Hemant, J.P., Girdhar, M.T. and Hatim, F.D. Effect of Fagonia Arabica (Dhamasa) on in vitro thrombolysis.BMC Complementary and Alternative Medicine;7: 2007, 7-36.

[27]. Khanna, A.K., Chander, R., Singh, C., Srivastava, A.K. and Kapoor, N.K. Hypolipidemic activity of Achyranthes aspera Linn. in normal and triton induced hyperlipemic rats, Indian J. Exp. Biol., 30(2), 1992, 128-130.

[28]. Verstraete, M. Third generation thrombolytic drugs.Am J Med; 109(1), 2000, 52-58.

[29]. Wu, D.H., Shi, G.Y., Chuang, W.J., Hsu, J.M., Young, K.C. and Chang, C.W. Coiled coil region of streptokinase gamma-domain is essential for plasminogen activation. J Biol Chem. 276: 2001, 15025-15033.

[30]. Nicolini, F.A., Nichols, W.W., Mehta, J.L., Saldeen, T.G., Schofield, R., Ross, M., Player, Pohl, W.D. and Mattsson, C. Sustained reflow in dogs with coronary thrombosis with K2P, a novel mutant of tissue plasminogen activator. J Am Coll Cardiol. 20, 1992, $228-235$.

[31]. Tahiliani, P. and Kar, A. Achyranthes aspera elevates thyroid hormone level and decrease hepatic lipid peroxidation in male rats, J.Ethanopharmacol.,71, 2000, 527-532..

[32]. Roy, V. Phytochemical investigation on a tropical plant. Pakistan Journal of Nutrition. 8 (1), 2009, 83-85.

[33]. Ayoola, G.A., Coker, H.A.B., Adesegun, S.A., Adepoju-Bello, A.A., Obaweya, K., Ezennia, E.C. and Atangbayila, T.O. Phytochemical Screening and Antioxidant Activities of Some Selected Medicinal Plants Used for Malaria Therapy in Southwestern Nigeria. Tropical Journal of Pharmaceutical Research. 7 (3), 2008, 1019-1024.

[34]. Edeoga, H.A., Okwu, D.E. and Mbaebie, B.O. Phytochemical constituent of some Nigerian Medicinal Plants, African journal of Biotechnology academic journals. 4: 2005, 685-688.

[35]. McLaughin. Cytotoxicity. Drug Information Journal, 32: 1988, 513-524.

[36]. Meyer, B. N., Ferrigni, N. R., Putnam, J. E., Jacobson, L. B., Nichols, D. E. and McLaughlin, J. L. Brine shrimp: a convenient general bioassay for active plant constituents. Planta Medica, 45: 1982, 31-34.

[37]. Persoone, G., Proceeding of the International Symposium on Brine Shrimp, Artemia salina. Vol.1-3 1980.Universa Press, Witteren, Belgium.

[38]. Umamaheswari, M., Dhinesh, S., Sivashanmugam, T., Subhadradevi, V., Puliyath, J. 2012. and Madeswaran, A. 2012. Anticataract and antioxidant activities of Achyranthes aspera Linn. against glucose-induced cataractogenesis using goat lenses $J$. Nat. Prod. Plant Resour., 2 (1):153-161

[39]. Neogi, N.C., Garg, R.D. and Rathor, R.S. Preliminary pharmacological studies on achyranthine, Indian Journal of Pharmacy, 32(2), 1970, 43.

[40]. Harborne, J.B. Phytochemical Methods: A Guide to Modern Techniques of plant Analysis. Chapman and Hall Ltd, London. 1973, p. 279.

[41]. Aqil, F., Ahmed, I. and Mehmood, Z. Antioxidant and free radical scavenging properties of twelve traditionally used Indian medicinal plants. Turk J Biol, 30, 2006, 177-183.

[42]. Urquiaga, I.; Leighton, F.; Plant polyphenol, antioxidants and Oxidative stress. Biol. Res. 33: 2000, $159-165$.

[43]. Okwu, DE. and Okwu, ME. Chemical composition of Spondias mombin Linn. Plant parts. J. Sustain. Agric Environ. 6 (2), 2004, 140-147.

[44]. Okwu, DE; Evaluation of the chemical composition of indigenous spices and flavouring Agents. Global J. Pure Appl. Sci. 7(3), 2001, 455- 459 .

[45]. Hullatti, K.K. and Murthy, U.D. Activity guided isolation of Cytotoxic compounds from Indian medicinal plants using BSL bioassay, Journal of Current Pharmaceutical Research, 1, 2010, 16-18.

[46]. Rieser, M. J.; Gu, Z.-M., Fang, X.-P.; Zeng, L.; Wood, K. V.; \& McLaughlin, J. L.; Five novel mono-tetrahydrofuran ring acetogenins from the seeds of Annona muricata. Journal of Natural Products, 59, 1996, 100-108.

[47]. Jerry L. Mclaughlin, Lingling L. Rogers \& Jon E. Anderson. The use of Biological assays to evaluate Botanicals. Drug information journal, vol.32, 1998, pp.513-524. 